\title{
Household processing and dissemination of tomato paste technology
}

\author{
K. O. Zaka \\ Nigerian Stored Product Research Institute, Nigeria
}

\begin{abstract}
Three varieties of local tomatoes were processed into paste using a simple household processing technique to preserve the product. The chemical and proximate composition and sensory acceptability of the product were determined with storage period. Protein content, ether extract and ash contents were in the range of $1.12-2.90 \%, 0.28-0.56 \%$ and $4.39-6.32 \%$ respectively. $\mathrm{pH}$, titratable acidity and total soluble solid content of the products with storage period were in the range of $4.23-4.72,0.021-0.037 \%$ and $12-15 \%$ respectively. The paste from the varieties had different acceptability but none was rejected.
\end{abstract}

Keywords: tomatoes, food processing, extension.

\section{Introduction}

High post-harvest losses have been associated with many tropical and subtropical fruits due to lack of appropriate processing and storage technologies. Post-harvest losses of fruits and vegetables are extremely high in Nigeria (30$50 \%$ ), exacerbated by poor marketing, distribution and storage facilities (Aworh [1]). Tomato (Lycopersion esculentum) is an important vegetable grown in Nigeria. It is a rich source of natural vitamins and minerals in preventing scurvy and boosting the immune system and enhancing rapid healing (Bakhru [2]). Tomatoes in their fresh forms have high water content which makes them readily susceptible to mechanical injury, desiccation and pathological attack. Fresh produce contains up to $95 \%$ water and this is sufficiently moist to support both enzymic activity and growth of microorganisms (FAO [4]). Fruits and vegetables are inherently more liable to deterioration under tropical conditions characterized by high temperatures and humidity and high incidence of pests and disease. The importance of good post-harvest practices in minimizing post-harvest losses 
cannot be overemphasized. Appropriate pre-harvest practices, harvesting and post-harvest chain will result in superior quality produce. Tomatoes being highly perishable commodities at ambient storage can be converted into shelf- stable convenience products through value addition technologies. This study is therefore conducted with the following objectives:

1. To study the chemical qualities and consumer acceptance of household processed tomato paste.

2. To disseminate the processing technology to end users.

\section{Materials and methods}

Fresh tomatoes: Alawusa (TX1), a local variety with four lobes (TX2), and a local variety with two lobes (TX3), were obtained from a local market Bodija in Ibadan, Nigeria.

\subsection{Preparation of tomato paste}

Tomatoes $(500 \mathrm{~g})$ of each variety were washed in clean water. Each variety was separately processed as shown in Figure 1. The tomatoes were cut and ground in a warring blender. A cube of sugar was added to the ground tomatoes then concentrated by boiling for 30 mins. The concentrated tomatoes were poured into sterilized glass jars and allowed to cool. Vegetable oil was used to cover the top of the product to seal off air. The jar was sealed with its cover and the product was stored at ambient temperature $28+2{ }^{0} \mathrm{C} . \mathrm{pH}$. Titratable acidity (\%TTA) and total soluble solid (\%TSS) of the products were determined at three days interval for two weeks. Initial proximate composition of the fresh tomato paste and final composition after the storage period were determined. Sensory acceptability of the product was determined at seven day intervals for two weeks.

\subsection{Chemical analyses}

$\mathrm{pH}$ and titratable acidity were determined in triplicate according to standard methods as described by Kirk and Sawyer [5]. $\mathrm{pH}$ of the samples was determined using $\mathrm{pH}$ meter (Metrohm 620) calibrated with buffers 4 and 7. Titratable acidity of the samples was determined by titrating $5 \mathrm{~g}$ of the samples with $0.1 \mathrm{~N}$ sodium hydroxide using phenolphthalein as indicator. Total soluble content of the tomato paste was determined using Abee Refractometer. Protein content, ether extract, crude fibre, ash and moisture content were determined using method of AOAC $[5]$.

\subsection{Consumer acceptability test}

Coded samples of tomato paste were presented to a panel of ten judges. They were asked to evaluate the samples for different attributes: appearance, colour, flavour, taste and overall acceptability. The panellists were provided with a mouth rinse in between each tasting. The attributes were scored using a five 
point hedonics scale where five equals like extremely and one equals dislike extremely (Iwe [6]).

\subsection{Dissemination of the tomato paste technology}

Demonstration of the technology was to women groups in a rural community, Odo Ona Kekere in Oyo State, Nigeria. Forty women were trained on the utilization of the technology.

\section{Results and discussion}

Table 1 shows the results of changes in PH, TTA and TSS of the tomato pastes with each storage period. Results of the study shows that $\mathrm{pH}$ of the tomatoes

Table 1: $\quad \mathrm{pH}$, Titratable acidity and total soluble solids of tomato paste from different varieties of tomatoes during storage.

\begin{tabular}{|c|c|c|c|c|}
\hline Storage day & Samples & $\mathrm{pH}$ & TTA (\%) & TSS (\%) \\
\hline \multirow[t]{3}{*}{0} & TX1 & $4.42 \mathrm{~d}$ & $0.028 \mathrm{a}$ & $15 \mathrm{a}$ \\
\hline & TX2 & $4.51 \mathrm{c}$ & $0.037 \mathrm{a}$ & $13 a$ \\
\hline & TX3 & $4.54 \mathrm{c}$ & $0.037 \mathrm{a}$ & $13 a$ \\
\hline \multirow[t]{3}{*}{3} & TX1 & $4.23 \mathrm{e}$ & $0.028 \mathrm{a}$ & $15 \mathrm{a}$ \\
\hline & TX2 & $4.26 \mathrm{e}$ & $0.021 \mathrm{a}$ & $13 a$ \\
\hline & TX3 & $4.26 \mathrm{e}$ & $0.035 \mathrm{a}$ & $13 a$ \\
\hline \multirow[t]{3}{*}{6} & TX1 & $4.40 \mathrm{~b}$ & $0.036 \mathrm{a}$ & $14 \mathrm{a}$ \\
\hline & TX2 & $4.45 d$ & $0.036 \mathrm{a}$ & $12 \mathrm{ab}$ \\
\hline & TX3 & $4.51 \mathrm{c}$ & $0.037 \mathrm{a}$ & $12 \mathrm{ab}$ \\
\hline \multirow[t]{3}{*}{9} & TX1 & $4.48 \mathrm{~d}$ & $0.028 \mathrm{a}$ & $14 \mathrm{a}$ \\
\hline & TX2 & $4.47 \mathrm{~d}$ & $0.029 a$ & $12 \mathrm{ab}$ \\
\hline & TX3 & $4.51 \mathrm{c}$ & $0.031 \mathrm{a}$ & $12 \mathrm{ab}$ \\
\hline \multirow[t]{3}{*}{12} & TX1 & $4.72 a$ & $0.032 \mathrm{a}$ & $14 a b$ \\
\hline & TX2 & $4.64 b$ & $0.034 a$ & $12 \mathrm{ab}$ \\
\hline & TX3 & $4.58 \mathrm{c}$ & $0.035 \mathrm{a}$ & $12 \mathrm{ab}$ \\
\hline
\end{tabular}

Means in the same column with different superscripts are significantly different at $5 \%$ level.

Key: TX1=Alawusa, TX2= Local tomatoes with four lobes

TX3=Local tomatoes with two lobe 
ranged from 4.26-4.72 during the storage period. Alawusa TX1 ranged 4.404.72, TX2 from 4.26-4.64 and TX3 from 4.26-4.58. This shows that there was an increase in the $\mathrm{pH}$ with the storage period with the all the varieties of tomatoes processed into paste. $\mathrm{pH}$ is an indicator for the state of acidity or alkalinity. The titratable acidity of the sample was within the range of 0.021 and $0.037 \%$ which was not significantly different with the storage period. In addition, the total solid content of the paste ranged from $12-15 \%$ depending on the varieties of the tomatoes which was not significantly different at $p<0.05$. Initial total soluble solid contents of TX1, TX2 and TX3 was not significantly different $(\mathrm{P}<0.05)$ after day 6 and day 12 of storage. This shows that total solid content of the purees did not change with storage period.

Table 2: Chemical composition of tomato paste from different varieties of tomatoes during storage.

\begin{tabular}{|c|c|c|c|c|c|c|}
\hline $\begin{array}{c}\text { Storage } \\
\text { day }\end{array}$ & Samples & $\begin{array}{c}\text { Crude } \\
\text { protein } \\
\%\end{array}$ & $\begin{array}{c}\text { Ether } \\
\text { extract } \\
(\%)\end{array}$ & $\begin{array}{c}\text { Ash } \\
(\%)\end{array}$ & $\begin{array}{c}\text { Moisture } \\
\%\end{array}$ & $\begin{array}{c}\text { Dry } \\
\text { matter } \\
\%\end{array}$ \\
\hline \multirow{2}{*}{0} & TX1 & $2.68 \mathrm{a}$ & $0.51 \mathrm{a}$ & $4.39 \mathrm{c}$ & $28.3 \mathrm{~b}$ & $71.7 \mathrm{~b}$ \\
\cline { 2 - 7 } & TX2 & $2.75 \mathrm{a}$ & $0.53 \mathrm{a}$ & $4.60 \mathrm{c}$ & $27.9 \mathrm{~b}$ & $72.1 \mathrm{~b}$ \\
\cline { 2 - 7 } & TX3 & $2.82 \mathrm{a}$ & $0.56 \mathrm{a}$ & $4.45 \mathrm{c}$ & $28.7 \mathrm{~b}$ & $71.3 \mathrm{~b}$ \\
\hline \multirow{2}{*}{3} & TX1 & $2.79 \mathrm{a}$ & $0.47 \mathrm{ab}$ & $4.91 \mathrm{c}$ & $23.4 \mathrm{c}$ & $73.8 \mathrm{ab}$ \\
\cline { 2 - 7 } & TX2 & $2.83 \mathrm{a}$ & $0.42 \mathrm{ab}$ & $5.71 \mathrm{~b}$ & $24.9 \mathrm{c}$ & $73.6 \mathrm{ab}$ \\
\cline { 2 - 8 } & TX3 & $2.90 \mathrm{a}$ & $0.41 \mathrm{ab}$ & $6.32 \mathrm{a}$ & $23.4 \mathrm{c}$ & $75.2 \mathrm{a}$ \\
\hline \multirow{2}{*}{6} & TX1 & $1.42 \mathrm{~b}$ & $0.37 \mathrm{~b}$ & $5.51 \mathrm{~b}$ & $26.7 \mathrm{bc}$ & $72.1 \mathrm{~b}$ \\
\cline { 2 - 8 } & TX2 & $1.38 \mathrm{~b}$ & $0.35 \mathrm{~b}$ & $5.31 \mathrm{~b}$ & $27.1 \mathrm{bc}$ & $72.8 \mathrm{~b}$ \\
\cline { 2 - 8 } & TX3 & $1.46 \mathrm{~b}$ & $0.34 \mathrm{~b}$ & $5.39 \mathrm{~b}$ & 29.2 & $73.3 \mathrm{ab}$ \\
\hline \multirow{2}{*}{9} & TX1 & $1.23 \mathrm{~b}$ & $0.32 \mathrm{~b}$ & $5.81 \mathrm{~b}$ & $28.3 \mathrm{~b}$ & $72.2 \mathrm{~b}$ \\
\cline { 2 - 8 } & TX2 & $1.22 \mathrm{~b}$ & $0.31 \mathrm{~b}$ & $5.61 \mathrm{~b}$ & $28.4 \mathrm{~b}$ & $71.6 \mathrm{~b}$ \\
\cline { 2 - 8 } & TX3 & $1.12 \mathrm{~b}$ & $0.31 \mathrm{~b}$ & $5.73 \mathrm{~b}$ & $29.3 \mathrm{~b}$ & $70.7 \mathrm{~b}$ \\
\hline \multirow{2}{*}{12} & TX1 & $1.18 \mathrm{~b}$ & $0.28 \mathrm{bc}$ & $5.84 \mathrm{~b}$ & $29.7 \mathrm{~b}$ & $72.3 \mathrm{~b}$ \\
\cline { 2 - 8 } & TX2 & $1.17 \mathrm{~b}$ & $0.29 \mathrm{bc}$ & $5.72 \mathrm{~b}$ & $29.6 \mathrm{~b}$ & $73.3 \mathrm{ab}$ \\
\cline { 2 - 7 } & TX3 & $1.18 \mathrm{~b}$ & $0.29 \mathrm{bc}$ & $5.76 \mathrm{~b}$ & $30.2 \mathrm{a}$ & $70.1 \mathrm{~b}$ \\
\hline
\end{tabular}

Means in the same column with different superscripts are significantly different at $5 \%$ level.

Key: TX1=Alawusa, TX2= Local tomato with four lobes

$\mathrm{TX} 3=$ Local tomato with two lobes 
The chemical composition of the varieties of tomato paste with storage period is shown in Table 2. The crude protein content of the puree ranged from 1.12$2.90 \%$. Trend in the study of the crude protein content with storage days shows that crude protein content generally decreased after the $3^{\text {rd }}$ day of storage while the protein content unchanged after the $6^{\text {th }}$ day to the $12^{\text {th }}$ day of storage. The ether extract content decreased with storage days but data obtained for day 6 to 12 days of storage were not significantly different. However, ash content of the paste increased with storage days within the range of 4.39-6.32. Increase in ash content could be due to changes in the dry matter content with storage period. Dry matter content was in the range of $70.7-75.2 \%$.

Table 3 shows the sensory acceptability of the tomato paste with the storage period. The sensory characteristics of the paste monitored at weekly interval shows that Alawusa TX1 was most preferred in appearance. The appearance of TX1 paste did not significantly change day 7 (week1) and day 14 (week 2) of storage. Result of the colour of TX1 did not significantly change after 7 days of storage. The scoring of taste after day 14 shows that the paste from all the varieties was not significantly from the initial scoring for day 0 . However for flavour and overall acceptability, sample TX3 was only preferred within 7 days of storage in comparison with TX1 and TX2 which were still preferred within the 14 days of storage. Sensory study of the tomato paste is important in determining the extent of acceptability of the products of the developed technology.

Table 3: Sensory acceptability of tomato paste from different varieties of tomatoes during storage.

\begin{tabular}{|c|c|c|c|c|c|c|}
\hline $\begin{array}{c}\text { Storage } \\
\text { day }\end{array}$ & Sample & Appearance & Colour & Taste & Flavour & $\begin{array}{c}\text { Overall } \\
\text { acceptability }\end{array}$ \\
\hline \multirow{2}{*}{0} & TX1 & $4.0 \mathrm{a}$ & $4.3 \mathrm{a}$ & $3.8 \mathrm{a}$ & $3.8 \mathrm{ab}$ & $3.6 \mathrm{~b}$ \\
\cline { 2 - 7 } & $\mathrm{TX} 2$ & $3.5 \mathrm{~b}$ & $3.7 \mathrm{~b}$ & $4.0 \mathrm{a}$ & $3.9 \mathrm{a}$ & $3.6 \mathrm{~b}$ \\
\cline { 2 - 7 } & $\mathrm{TX} 3$ & $3.5 \mathrm{~b}$ & $3.5 \mathrm{bc}$ & $3.7 \mathrm{ab}$ & $3.3 \mathrm{bc}$ & $2.8 \mathrm{ab}$ \\
\hline \multirow{2}{*}{7} & $\mathrm{TX} 1$ & $4.0 \mathrm{a}$ & $4.3 \mathrm{a}$ & $3.4 \mathrm{c}$ & $4.0 \mathrm{a}$ & $3.8 \mathrm{a}$ \\
\cline { 2 - 7 } & $\mathrm{TX} 2$ & $2.9 \mathrm{c}$ & $3.9 \mathrm{~b}$ & $3.8 \mathrm{a}$ & $4.2 \mathrm{a}$ & $3.0 \mathrm{a}$ \\
\cline { 2 - 7 } & $\mathrm{TX} 3$ & $3.4 \mathrm{~b}$ & $2.9 \mathrm{~d}$ & $3.6 \mathrm{ab}$ & $3.5 \mathrm{c}$ & $2.9 \mathrm{a}$ \\
\hline \multirow{2}{*}{14} & $\mathrm{TX} 1$ & $3.9 \mathrm{a}$ & $3.5 \mathrm{~b}$ & $3.0 \mathrm{c}$ & $3.3 \mathrm{bc}$ & $3.1 \mathrm{a}$ \\
\cline { 2 - 7 } & $\mathrm{TX} 2$ & $3.2 \mathrm{bc}$ & $3.4 \mathrm{bc}$ & $3.5 \mathrm{ab}$ & $3.2 \mathrm{bc}$ & $2.7 \mathrm{ab}$ \\
\cline { 2 - 7 } & $\mathrm{TX} 3$ & $2.4 \mathrm{~cd}$ & $2.7 \mathrm{~d}$ & $3.6 \mathrm{ab}$ & $3.0 \mathrm{c}$ & $2.6 \mathrm{bc}$ \\
\hline
\end{tabular}

Means in the same column with different superscripts are significantly different at $5 \%$ level.

Key: TX1=Alawusa, TX2= Local tomatoes with four lobes

$\mathrm{TX} 3=$ Local tomatoes with two lobes 


\section{Conclusion}

Extension of this technology through demonstration to the rural women group is expected to reduce food losses, hence increasing food security.

\section{References}

[1] Aworh OC. Effect of post-harvest handling on quality of attributes of tomatoes in the Nigerian marketing system. Food Chemistry 10:225-230, 1983.

[2] Bakhru HK. Food that heals: the natural way to good health. Ravinda Printing Press, Delhi, India. pp.148, 2007.

[3] Kirk, RS. and Sawyer, R. Pearson's Chemical composition and Analysis of Foods. $9^{\text {th }}$ edition. Longman group Ltd. pp. 641-644, 1997.

[4] FAO. Prevention of post-harvest losses of fruits, vegetables and root crops: A training manual (Smith. K. eds). Series Number 17/2. Food and Agricultural Organization of the United Nations, Rome, 1989.

[5] AOAC. Official Methods of Analysis. Association of Official Analytical Chemists. Washington DC., 1984.

[6] Iwe MO. Handbook of Sensory Methods and Analysis. Rojoint Communication Services Limited, Enugu, Nigeria, 2002. 